\title{
Failure to find antianxiety properties of cholecystokinin-octapeptide
}

\author{
STEVEN L. COHEN and MELINDA S. CROUSE \\ Bloomsburg University of Pennsylvania, Bloomsburg, Pennsylvania
}

\begin{abstract}
Cholecystokinin octapeptide has been shown to retard acquisition and maintenance and to facilitate extinction of avoidance responding. This study attempted to determine whether the peptide has antianxiety properties that might contribute to these effects. Rats were trained to press a lever for food under a multiple random-interval 30-sec random-interval 30-sec schedule of reinforcement. In the presence of the second component, every eighth response also produced a brief electric shock (i.e., Geller conflict procedure). The introduction of shock decreased response rate. The anxiolytic chlordiazepoxide (3-24 mg/kg, subcutaneous) produced significant elevations in punished responding. Cholecystokinin octapeptide $(5-40 \mu \mathrm{g} / \mathrm{kg}$, subcutaneous) administered $1 \mathrm{~h}$ before the session did not affect response rate. The data fail to show that cholecystokinin octapeptide has antianxiety properties and suggest that reduction in "fear" following peptide administration is not responsible for its well-known effects on avoidance responding.
\end{abstract}

Cholecystokinin (CCK) is a peptide hormone originally identified in the gut and recently found within neurons of the central nervous system (e.g., Beinfeld, Meyer, Eskay, Jensen, \& Brownstein, 1981). CCK8, the physiologically active carboxyl terminal octapeptide, has been shown to inhibit food intake in several mammalian species and is a putative signal of short-term satiety (e.g., Gibbs, Young, \& Smith, 1973). A number of additional behavioral effects have been observed following the systemic injection of CCK8. For example, CCK8 has been shown to produce sedative-like effects (i.e., ptosis, reduced locomotion, depressed rearing, prolonged hexobarbital sleep) in mice (Zetler, 1980a, 1980b), to decrease exploration (Crawley, Hays, O'Donohue, Paul, \& Goodwin, 1981), and to reduce food- and water-reinforced operant responding in rats (Cohen, 1986; Cohen, Knight, Tamminga, \& Chase, 1983b, 1985).

CCK8 has also been shown to affect behavioral tasks that involve the presentation of electric shock. For example, CCK8 has been shown to reduce the maintenance of signaled and unsignaled avoidance responding (Cohen et al., 1982, 1983a), retard the acquisition and speed the extinction of active avoidance responding (Cohen et al., 1982; Fekete et al., 1984), and increase passive avoidance latency (Fekete, Kadar, Penke, \& Telegdy, 1981; Fekete et al., 1984).

Fekete et al. (1984) have suggested that CCK8 alters behavior on shock-related tasks by modifying fear motivation or arousal. It is unclear, however, if CCK8 might act to increase or decrease fear motivation. On one hand,

Melinda S. Crouse is presently at the Department of Psychology, University of Hartford, West Hartford, CT. Portions of this research were supported by a faculty-release-time award from Bloomsburg University. Requests for reprints may be sent to Steven L. Cohen, Department of Psychology, Bloomsburg University of Pennsylvania, Bloomsburg, PA 17815. it might be argued that CCK8 acts as a fear-reducing or antianxiety drug. For example, a reduction in fear following CCK8 administration might impair the acquisition and maintenance of active avoidance responding as well as facilitate its extinction. There is some evidence that CCK8 might have some properties of the antianxiety benzodiazepines. Zetler (1981a, 1981b), for example, showed that diazepam and CCK8 share some anticonvulsant effects. Human volunteers have reported diminished anxiety following the administration of ceruletide, a peptide chemically related to CCK8 (Basso et al., 1981). On the other hand, it might also be argued that a reduction in fear or anxiety following CCK8 should produce a decrease rather than an increase in passive avoidance latency (Fekete, Kadar, Penke, \& Telegdy, 1981; Fekete et al., 1984).

In light of these arguments, the present study was an attempt to directly test the antianxiety properties of CCK8. A widely used technique to study the antianxiety effects of drugs is the Geller conflict procedure (Geller \& Seifter, 1960; Houser, 1978). This procedure involves the use of a multiple schedule of reinforcement. In the presence of one component of the multiple schedule, responding is reinforced with food according to a variable- or randominterval (RI) schedule of reinforcement. In the presence of the other component, responding produces food and electric shock. Responding is suppressed in the food-shock component, and anxiolytic compounds, such as meprobamate, chlordiazepoxide (CHL), and diazepam, typically produce an elevation in punished responding. In the present experiment, rats were trained to respond for food under the conflict procedure and then given CHL or CCK8. The rats given CHL were expected to show an increase in response rate in the shock component of the multiple schedule. An increase in response rate following CCK8 would be evidence of an anxiolytic effect. 


\section{METHOD}

\section{Subjects}

Fourteen experimentally naive male albino Sprague-Dawley (Camm Research) rats were maintained at $80 \%$ (310 to $387 \mathrm{~g}$ ) free-feeding body weight throughout the experiment. Rats had free access to water, were individually caged, and were kept on a 12:12 h light:dark cycle, with lights on starting at 0600 .

\section{Apparatus}

Six identical modular operant conditioning chambers for rats (Coulbourn Instruments) were housed in sound-attenuated cubicles. Each chamber had a food cup in the bottom center of the work panel, and the response lever was situated to the right of the food cup $22 \mathrm{~mm}$ from the side wall and $28 \mathrm{~mm}$ above the grid floor. A minimum force of approximately $.24 \mathrm{~N}$ was required to operate the response lever. A 28-V houselight was located above the food cup near the top of the chamber. Reinforcement (45-mg Noyes food pellets) was delivered by a Gerbrands pellet feeder. White noise was continuously present to mask extraneous noise. Shock was delivered to the grid floor of each chamber by Coulbourn solid-state shock distributors. Experimental sessions were controlled by an IBM PC, Coulbourn Instruments Lab-Linc Interface, and Pascal programming.

\section{Compounds}

Sulfated CCK8 (Boehringer Mannheim) was dissolved in physiological saline, with $1 M$ sodium bicarbonate added $(25 \mu \mathrm{l} / \mathrm{ml})$ to raise the $\mathrm{pH}$ to neutrality. CCK8 control injections of saline also contained the sodium bicarbonate. The same batch of CCK8 had previously been used in another experiment and had been shown to be behaviorally active in suppressing leverpressing for water reinforcement when injected $60 \mathrm{sec}$ before the session. Chlordiazepoxide HCL (generously donated by Hoffman-La Roche, Inc.) was dissolved in distilled water.

\section{Procedure}

Each rat was randomly assigned to an operant chamber, trained to press the response lever using an autoshaping procedure, and given three sessions of continuous reinforcement. Rats were then given one session of training under an RI 1-sec schedule, one session under an RI 10sec schedule, and five sessions under an RI 30-sec schedule of reinforcement. Under the RI 30-sec schedule, the first response following an average interval of $30 \mathrm{sec}$ (minimum of $1 \mathrm{sec}$, maximum of $60 \mathrm{sec}$ ) delivered a food pellet, turned off the houselight, and turned on the hopperlight for $5 \mathrm{sec}$. Responses during the 5 -sec food cycle had no scheduled consequences.

Rats were then placed on a multiple (mult) RI 30-sec RI 30-sec schedule. In the presence of Component 1 (the houselight flashing on and off each $.3 \mathrm{sec}$ ) and Component 2 (steady houselight), responses were reinforced according to the RI 30-sec schedule. Each component lasted $180 \mathrm{sec}$ and was separated by a 4-sec blackout when the chamber was dark and responses had no scheduled consequences. Components alternated during the session. Each session began with Component 1 and terminated automatically following a total of 12 components. Reinforcement scheduled but not delivered in one component was canceled when components alternated. Sessions were conducted Monday through Friday.

Rats were maintained on this schedule for 20 sessions before shock was introduced. While the multiple schedule of reinforcement remained in effect, a .75-sec shock was delivered in Component 2 following every eighth response (a fixed-ratio [FR] 8 schedule of shock presentation). Responses produced in Component 2 when the component terminated were counted toward the FR 8 when Component 2 was reinstated. The shock level for each rat was adjusted over sessions until no increasing or decreasing changes in response rates were observed for at least five sessions. Shock produced an average $77 \%$ (range $26 \%$ $89 \%$ ) reduction in response rate in Component 2 over nonshock baseline response rates. Shock levels ranged from .1-.3 mA.

Rats were given 35 sessions of shock before drugs were introduced. Rats were randomly assigned to two equal groups. Group 1 received CCK8 injections of $0,5,10,40 \mu \mathrm{g} / \mathrm{kg} 60 \mathrm{~min}$ before a session. Group 2 received CHL injections of $0,3,6,24 \mathrm{mg} / \mathrm{kg} 30 \mathrm{~min}$ before a session. Four rats in each group were given the doses in ascending order and
3 in descending order. Injections were given subcutaneously on the dorsal part of the neck in a volume of $2.5 \mathrm{ml} / \mathrm{kg}$. There was a minimum of four sessions between injections.

\section{RESULTS}

The main datum in this study was response rate in Component 2 of the multiple schedule in which responding was reinforced with food according to an RI 30-sec schedule and every eighth response produced a brief electric shock. Figure 1 summarizes the results of the experiment. Data were analyzed with nonparametric statistics because of large within-group variability. Before shock was introduced (PRE), both groups of rats were responding at a high constant response rate. For each rat, response rate in Component 2 was averaged over the last five sessions before shock was delivered. The mean response rate of these preshock averages was 32.3 and 49.7 responses per minute for CCK8 and CHL groups, respectively. A MannWhitney $U$ test indicated that before shock was introduced the two groups did not differ significantly from each other $(U=14)$. The presentation of shock decreased response rate. Baseline response rate (B) under the FR 8 shock condition was calculated by averaging the response rate in Component 2 for every preinjection session. Average

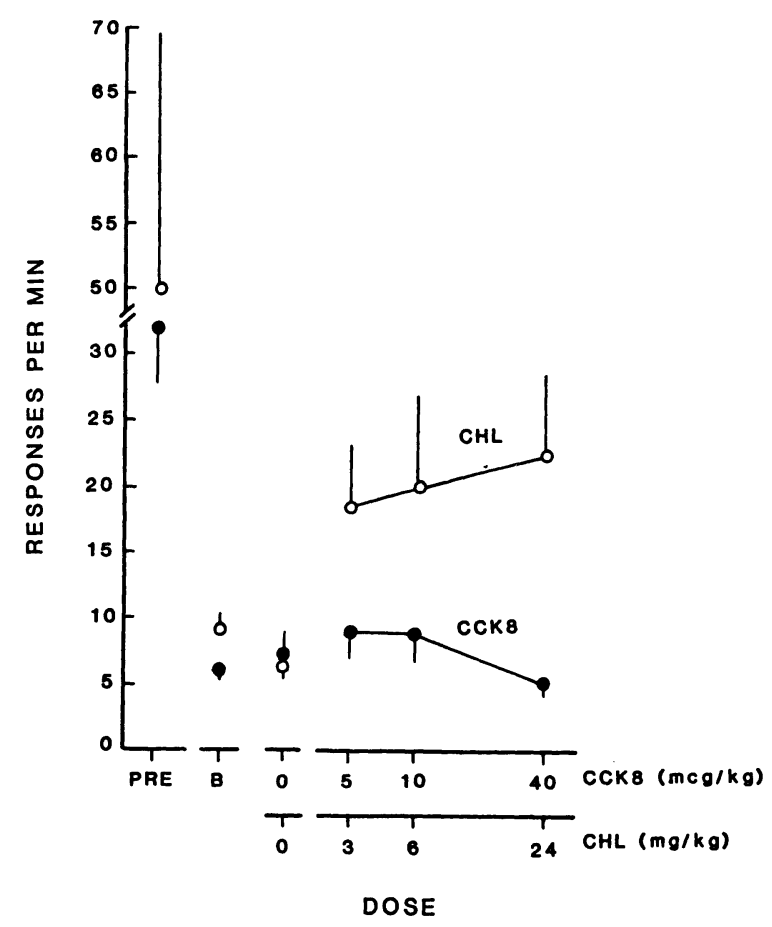

Figure 1. Response rate in Component 2 of the multiple schedule. Responding produced food according to an RI 30 -sec schedule and shock according to an FR 8 schedule. Rats were given cholecystokinin-octapeptide (CCK8, filled circles) or chlordiazepoxide (CHL, open circles). Data above PRE represent response rate before shock was introduced in the multiple schedule. Data above B represent baseline response rate during sessions immediately preceding an injection session. Data are group means and standard errors of the mean; $\mathrm{mcg} / \mathrm{kg}$ stands for $\mu \mathrm{g} / \mathrm{kg}$. 
baseline response rate for CCK8 and CHL groups (6.2 and 9.2 responses per minute, respectively) were not significantly different from each other (Mann-Whitney $U$ test, $z=1.48$ ). Injections of CCK8 failed to produce a significant change in response rate. A Wilcoxon matchedpairs signed-ranks test comparing response rate following 5,10 , and $40 \mu \mathrm{g} / \mathrm{kg} \mathrm{CCK8}$ with response rate following a control injection of saline $(0 \mu \mathrm{g} / \mathrm{kg})$ found no significant change following CCK8 injection $(T=9,14$, and 12 , respectively). CHL injections, however, produced a significant increase in response rate. A Wilcoxon test comparing response rate following 3,6, and $24 \mathrm{mg} / \mathrm{kg} \mathrm{CHL}$ with response rate following a control injection of saline $(0 \mathrm{mg} / \mathrm{kg})$ found significant increases at all doses $(T=0$, 3 , and 1 , respectively, $p<.05$, one-tailed).

\section{DISCUSSION}

The introduction of electric shock in Component 2 of the multiple schedule produced a large reduction in response rate. Injections of CHL, a known anxiolytic, resulted in a significant elevation in punished responding. Injections of $\mathrm{CCK} 8$, however, failed to produce any change in punished responding.

CCK8 has been shown to affect acquisition, maintenance, and extinction of shock-avoidance behaviors (Cohen et al., 1982, 1983a; Fekete, Kadar, Penke, \& Telegdy, 1981; Fekete et al., 1984; Fekete, Szabo, Balazs, Penke, \& Telegdy, 1981). For example, rats trained to run back and forth in a shuttlebox to avoid shock in a free-operant (Sidman) avoidance paradigm run less and receive more shock following CCK8 administration (Cohen et al., 1983a). CCK8 also results in faster extinction of responding in both one- and two-way avoidance tasks when shock presentation is discontinued (Cohen et al., 1982; Fekete et al., 1984). It might be argued that a reduction in fear motivation following CCK8 might contribute to these effects. There is some evidence that CCK8 might share some properties of the antianxiety benzodiazepines such as anticonvulsant effects in mice (Zetler, 1981a, 1981b) and lower anxiety in humans (Basso et al., 1981). However, the present data suggest that fear reduction is not likely to account for the effects reported in shock-related paradigms.

Although the present study examined a wide range of CCK8 doses, we did not manipulate the mode of administration or the time between an injection and the start of the session. Subcutaneous injections were used because Fekete et al. (1984) reported that subcutaneous injections were 3 to 10 times more effective than intraperitoneal injections in the extinction of active avoidance responding. A time period of $1 \mathrm{~h}$ between an injection and the start of the session was chosen because CCK8 administered $1 \mathrm{~h}$ before a retention test has been shown to increase passive avoidance latency (Fekete, Kadar, Penke, \& Telegdy, 1981; Fekete et al., 1984), and if administered $2 \mathrm{~h}$ before an extinction test facilitates extinction of active avoidance (Fekete et al., 1984). Although other time periods and modes of administration may have revealed antianxiety effects, the parameters used in the present study were within the values shown to be effective in previous research.

\section{REFERENCES}

Basso, N., Materia, A., D'Intinosante, V., Ginaldi, A., Pona, V., ReIlly, P., RugGeri, S., \& Fioravanti, M. (1981). Effect of ceruletide on pituitary-hypothalamic peptides and on emotion in man. Peptides, 2, 71-75.
Beinfeld, M. C., Meyer, D. K., Eskay, R. L., Jensen, R. T., \& Brownstein, M. J. (1981). The distribution of cholecystokinin immunoreactivity in the central nervous system of the rat as determined by radioimmunoassay. Brain Research, 212, 51-57.

COHEN, S. L. (1986). A pharmacological examination of the resistanceto-change hypothesis of response strength. Journal of the Experimental Analysis of Behavior, 46, 363-379.

Cohen, S. L., Knight, M., Tamminga, C. A., \& Chase, T. N. (1982). Cholecystokinin-octapeptide effects on conditioned-avoidance behavior, stereotypy and catalepsy. European Journal of Pharmacology, 83, 213-222.

Cohen, S. L., Knight, M., Tamminga, C. A., \& Chase, T. N. (1983a). Tolerance to the anti-avoidance properties of cholecystokininoctapeptide. Peptides, 4, 67-70.

Cohen, S. L., Knight, M., Tamminga, C. A., \& Chase, T. N. (1983b). Minimized tolerance to the suppressive effects of CCK8 on operant responding. Behavioral \& Neural Biology, 39, 123-127.

Cohen, S. L., Knight, M., Tamminga, C. A., \& Chase, T. N. (1985). A comparison of peripheral and central effects of CCK8 on waterreinforced operant responding. European Journal of Pharmacology, 116, 229-238.

Crawley, J. N., Hays, S. E., O’Donohue, T. L., Paul, S. M., \& GoodwIN, F. K. (1981). Neuropeptide modulation of social and exploratory behaviors in laboratory rodents. Peptides, 2, 123-130.

Fekete, M., Kadar, T., Penke, B., \& Telegdy, G. (1981). Modulation of passive avoidance behavior by cholecystokinin octapeptides in rats. Neuropeptides, 1, 301-307.

Fekete, M., Lengyel, A., Hegedus, B., Penke, B., Zarandy, M., ToTH, G. K., \& TELEGDY, G. (1984). Further analysis of the effects of cholecystokinin octapeptides on avoidance behavior in rats. European Journal of Pharmacology, 98, 79-91.

Fekete, M., Szabo, A., Balazs, M., Penke, B., \& Telegdy, G. (1981). Effects of intraventricular administration of cholecystokinin octapeptide sulfate ester and unsulfated cholecystokinin octapeptide on active avoidance and conditioned feeding behavior of rats. Acta Physiologica Academiae Scientiarum Hungaricae, Tomus, 58, 39-45.

Geller, I., \& SeIFTER, J. (1960). The effects of meprobamate, barbiturates, $d$-amphetamine and promazine on experimentally induced conflict in the rat. Psychopharmacologia, 1, 482-492.

GibBs, J., Young, R. C., \& SMITH, G. P. (1973). Cholecystokinin decreases food intake in rats. Journal of Comparative \& Physiological Psychology, 84, 488-495.

HousER, V. P. (1978). The effects of drugs on behavior controlled by aversive stimuli. In D. E. Blackman \& D. J. Sanger (Eds.), Contemporary research in behavioral pharmacology (pp. 69-157). New York: Plenum Press.

ZetLer, G. (1980a). Analgesia and ptosis caused by caerulein and cholecystokinin octapeptide (CCK-8). Neuropharmacology, 19, 415-422.

ZETLER, G. (1980b). Effects of cholecystokinin-like peptides on rearing activity and hexobarbital-induced sleep. European Journal of Pharmacology, 66, 137-139.

ZETLER, G. (1981a) Anticonvulsant effects of caerulein, cholecystokinin octapeptide (CCK-8) and diazepam against seizures produced in mice by harman, thiosemicarbazide and isoniazid. Neuroscience Letters, 24, 175-180.

ZeTLER, G. (1981b) Central depressant effects of caerulein and cholecystokinin octapeptide (CCK-8) differ from those of diazepam and haloperidol. Neuropharmacology, 20, 277-283.

(Manuscript received for publication December 21, 1986.) 